\title{
Multiaxial notch fatigue life prediction based on the dominated loading modes under variable amplitude loading
}

\author{
Zhi-Qiang Tao ${ }^{1}$, Ming Zhang ${ }^{1}$, Yu Zhu ${ }^{1}$, Tian Cai ${ }^{1}$, Zi-Ling Zhang ${ }^{1}$, Hu Liu ${ }^{1}$, and Bin Bai ${ }^{1}$ \\ ${ }^{1}$ Affiliation not available
}

May 20, 2020

\begin{abstract}
An innovative computational methodology is proposed for fatigue life estimation of notched components subjected to multiaxial variable amplitude loadings. In the proposed methodology, if the calculated uniaxial fatigue damage by axial tension-compression loading path is more than that by the pure torsional loading path, an axial strain-based multiaxial fatigue damage parameter is selected to compute multiaxial fatigue damage, or else a shear strain-based multiaxial fatigue damage parameter is selected to compute multiaxial fatigue damage. Moreover, the proposed methodology utilizes axial strain-based and shear strainbased multiaxial fatigue damage parameters in replacement of equivalent strain amplitude to take into consideration of the non-proportional additional hardening phenomenon. The fatigue data of 7050-T7451 aluminum alloy and GH4169 superalloy notched specimens are utilized to verify the proposed notch fatigue life prediction methodology, and the prediction results are satisfactory.
\end{abstract}

\section{Hosted file}

Manuscript.doc available at https://authorea.com/users/324388/articles/452594-multiaxialnotch-fatigue-life-prediction-based-on-the-dominated-loading-modes-under-variableamplitude-loading

\section{Hosted file}

Table.doc available at https://authorea.com/users/324388/articles/452594-multiaxial-notchfatigue-life-prediction-based-on-the-dominated-loading-modes-under-variable-amplitudeloading

\section{Hosted file}

Figure.doc available at https://authorea.com/users/324388/articles/452594-multiaxial-notchfatigue-life-prediction-based-on-the-dominated-loading-modes-under-variable-amplitudeloading 